\title{
ICT Governance in the Context of Smart Cities: A Study in Brazilian Municipalities
}

\section{Luiz Claudio Diogo Reis ${ }^{1}$, Flavia Cristina Bernardini², Claudia Cappelli ${ }^{3}$, Simone Bacellar Leal Ferreira ${ }^{1}$}

${ }^{1}$ Instituto de Informática - Universidade Federal do Estado do Rio de Janeiro (UNIRIO) Av. Pasteur, 458 - Urca CEP 22290240 - Rio de Janeiro - RJ - Brasil

${ }^{2}$ Departamento de Computação - Universidade Federal Fluminense (UFF) - Niterói Rio de Janeiro - RJ - Brasil

${ }^{3}$ Departamento de Informática - Universidade do Estado do Rio de Janeiro (UERJ) Rio de Janeiro - RJ - Brasil

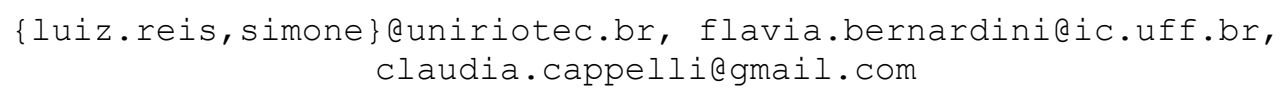

\begin{abstract}
ICT resources are essential to support, manage, and innovate cities services to citizens, especially in reference to smart cities context. From this perspective, ICT governance is fundamental to guarantee return on investments and effectiveness in cities' administration. Based on the Brazilian's cities best ranked in the Connected Smart Cities index, this work analyzed ICT governance practices in those cities. The results identified lack of governance practices in most cities, lack of active ICT governance transparency, and non-compliance of Brazilian access information law; thus, a set of lessons learned is structured for cities. Future studies can establish a good practice catalog and a guidance as a baseline for an ICT open governance approach.
\end{abstract}

Keywords. Smart Cities; Brazilian Municipalities; Public Sector; ICT Governance; Transparency; Information Access Law.

\section{Introduction}

The concept of Smart Cities has aroused the interest of government officials, private sector, research institutes, and citizens. According to [Gil-Gárcia et al. 2015], a fundamental principle applied to this context refers to the use of technology to improve services to citizens and promote sustainable economy, co-creation, and active participation of society in cities daily lives. According to those authors, the use of Information and Communication Technologies (ICT) resources can provide a range of solutions by applying Internet of Things, Big Data, and Artificial Intelligence applications, for instance.

ICTs permeate different areas, domains and sectors of a municipality, so its governance needs to be treated in a holistic, multidisciplinary, and transversal way, permeating all services provided to citizens. Thus, it is essential that the strategic planning of a city, included in its Master Plan, is aligned with ICT governance and that 
IT managers and professionals understand its importance, potential, and benefits [Brazil 2001].

Within the scope of the municipal public administration, ICT governance has a fundamental role, especially to transform the smartness of cities, considering that it involves significant investments and an alignment between cities' strategic objectives and each municipal secretariat. However, despite the relevance of ICT governance for smart cities, there is a limited amount of research that examined ICT governance mechanisms in this context [Connolly et al. 2017]. There is little research based on governance and a gap study on how governments manage smart cities [Bolívar 2016]. According to [Pereira et al. 2018], there has been no systematic effort to understand governance initiatives and how it is designed, planned, implemented and monitored to obtain better performance and responsiveness from smart cities. [Reis et al. 2020] also revealed that the COBIT 5 framework [ISACA, 2012], a reference guide for ICT governance in public and private organizations, has been poorly applied in the context of smart cities.

From a Brazilian perspective, [Boscarioli et al. 2017] described that smart city management represents one of the greatest challenges of Information Systems research area. Also, in an exploratory study in ten cities of Rio de Janeiro state, [Reis et al. 2020b] revealed lack of ICT governance requirements implementation. This study was extended and applied in fifteen Brazilian cities [Reis et al. 2021]. Thus, this research represents an expansion of the previous studies and analyzed ICT governance requirements in other thirty Brazilian cities best ranked in the Connected Smart Cities index [Connected Smart Cities, 2020], which is a ranking that qualifies the smartness and most connected cities in the country. The research methodology encompassed defining the required information, searching the cities' websites, requesting data based on Information Access Law [Brazil 2011], and a discussion of the findings. The objective of this study was to get a big picture of ICT governance practices in Brazilian smart cities context based on COBIT 2019 requirements [Reis et al. 2020b] [Reis et al. 2021] [Reis et al. 2021b].

This work is organized in five sections, including this foregoing introduction. Section 2 introduces the literature review on smart cities, ICT governance and related good practices. Section 3 describes the research methodology applied to conduct the study. Section 4 presents the research results and analyses ICT governance scenario in the related cities. Section 5 introduces the research conclusion, limitations, and future studies.

\section{Background}

\subsection{Smart Cities}

Smart city's theme has been a subject of discussions in the scientific community for some time, but it still can be considered as an abstract topic that lacks precision [Hollands 2008] [Kobayashi et al. 2017]. Some authors have defined domains to characterize cities as intelligent by proposing a broader approach to this topic, such as smart and sustainable cities that use ICT resources [Ahvenniemi et al. 2017]. Others addressed the differences between smart cities and digital cities, assuming that an intelligent system is associated with a digital system [Jucevicius et al. 2014]. With 
regards to this, a smart city must also be a digital city [Komninos et al. 2011] [Silva et al. 2016]. According to [Caragliu et al. 2011], an intelligent city system must have infrastructure, human capital, information and the capacity to generate knowledge.

Some authors associate the concept of smart cities with models or frameworks [Nam \& Pardo 2011]. [Gil-Gárcia et al. 2015] describe the main characteristics of smart cities in a framework composed of four dimensions and ten domains: Data and Technology (Data and Information; ICT and other Technologies); Physical Environment (Built Environment and City Infrastructure; Natural Environment and Ecological Sustainability); Society (Governance, Engagement and Collaboration; Human Capital and Creativity; Knowledge Economy and Pro-Business Environment); Government (Public Services; City Administration and Management; Institutional Arrangements).

According to ISO/IEC JTC 1, a smart city applies the new generation of Information and Communication Technologies (ICT), such as the Internet of Things (IoT), cloud computing, big data, and geographical information integration to facilitate the planning, the construction, the management, and the delivery of smart services to citizens [ISO/IEC JTC 1 2015]. From this perspective, ICT governance requisites are essential for smart cities, thus the following sections introduce governance foundations.

\subsection{ICT Governance Fundamentals}

ICT governance is associated with the handling of technology decisions and how they are orchestrated to serve different stakeholders in organizations [Huang et al. 2010]. In order to support organizations strategies and objectives, ICT governance mechanisms must be approved and supported by senior management and cover the entire organization [ITGI 2003] [Bianchi et al. 2017]. With regard to this, ICT governance composition can be based on structures (roles and responsibilities) and processes (ICT good practices), such as COBIT and ITIL [Nfuka \& Rusu 2011]. [De Haes \& Grembergen 2004] highlighted the importance of active participation and collaboration between stakeholders as good governance mechanisms, in which these components should interact to provide effective ICT governance results, as shown in Figure 1.

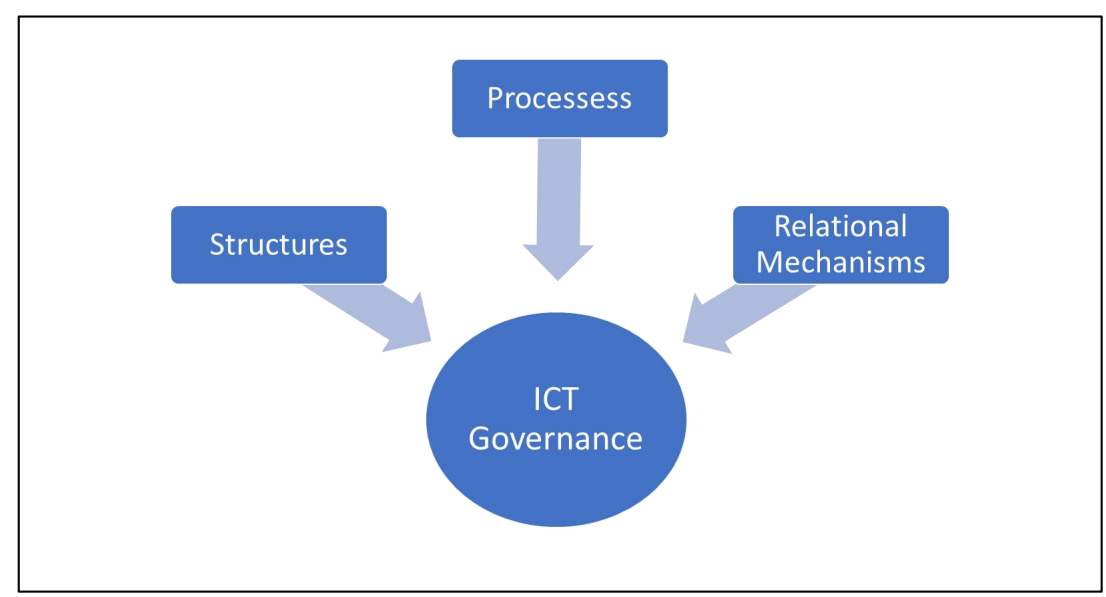

Figure 1. ICT Governance mechanisms

Source: Adapted from [De Haes e Grembergen 2004]

Together, these elements should provide the alignment of activities with ICT practices and provide benefits for the organization [Héroux \& Fortin 2017]. [Weill 2004] reveals that an effective ICT governance encourages and leverages the participation of 
all the organization's personnel, ensuring compliance with the vision and strategic objectives, to achieve a management paradox concerning both training and control. ICT governance represents a critical issue to avoid strategic, financial and operational losses [Singh 2009]. In this context, [Weill 2004] has shown that organizations that have adopted ICT governance practices have better returns on assets.

In another view, complementary to the previous one, ICT governance encompasses the description of policies, structures and process management related to IT functions, which implies (re)structuring processes, work practices and cultural environment [Weil \& Broadbent 2000] [Sohal and Fitzpatrick 2002]. Thus, ICT governance can be characterized in both technical and social perspectives. According to [Henderson and Venkatraman 1993] [Luftman et al. 1993], ICT decision making and accountability are central elements of governance and should include setting priorities and allocating IT services to ensure regulatory compliance and management partners [Luftman \& Kempaiah 2007]. According to [SISP 2017], ICT governance is a system in which the current and the future use of ICTs is directed and controlled by evaluating and directing its application to support and monitor the execution of strategic and operational plans. As described by COBIT 2019 [ISACA 2018], ICT corporate governance is exercised by the board that supervises the implementation of processes, structures and relational mechanisms based on responsibilities, strategic alignment, and value generation.

\subsubsection{ICT Governance Good Practices}

Several guidelines on how ICT governance can be implemented have emerged from the academia [De Haes \& Van Grembergen 2009] [Prasad et al. 2011]. The literature shows a significant role for ICT governance structures and standards based on good practices [De Haes et al. 2013]. For example, the COBIT framework, versions COBIT 5 and COBIT 2019, can be used for structuring corporate governance [ISACA 2012] [ISACA 2018] [De Haes et al. 2019] [Reis et al. 2020]. [Bartens et al. 2015] [Joshi et al. 2018] recognize that the successful implementation of ICT governance is a complex system and can be supported by good practices to assist organizations in this task.

The COBIT 5 framework is structured in seven interconnected factors that act as enablers in the implementation of ICT governance [ISACA 2012] [De Haes et al. 2019]. In COBIT 2019, these enablers are called governance components system [ISACA 2018]. Based on this, [Reis et al. 2020] characterized COBIT5 enablers in the context of smart cities and upgraded this study to COBIT 2019 governance system [ISACA 2018] [Reis et al. 2020b], as shown in Table 1.

Table 1. COBIT 2019 governance components for smart cities

\begin{tabular}{|c|l|}
\hline Governance component & \multicolumn{1}{c|}{ Smart city context description } \\
\hline $\begin{array}{c}\text { Principles, Frameworks, } \\
\text { and Models }\end{array}$ & $\begin{array}{l}\text { City leaders should consider guidelines, policies, rules, principles, partnerships, } \\
\text { and models related to ICT to drive cities strategic goals while planning their } \\
\text { digital and intelligent initiatives towards smart city projects. }\end{array}$ \\
\hline Internal Processes & $\begin{array}{l}\text { A set of ICT processes-based guidance that functions as a reference model } \\
\text { concerning standards, procedures, and goals should be in place to drive ICT } \\
\text { strategic and operational activities to support cities digital and smart projects. }\end{array}$ \\
\hline Organization Structure & $\begin{array}{l}\text { Organization structure that includes appropriate levels of responsibility, authority, } \\
\text { and decision-making related to ICT resources and investments concerning cities } \\
\text { digital and intelligent transformation should be considered in smart city ICT } \\
\text { governance and management context. }\end{array}$ \\
\hline Culture, ethics and & Culture, ethics, conduct code, and human behavior of city's ICT professionals and \\
\hline
\end{tabular}

iSys: Revista Brasileira de Sistemas de Informação (iSys: Brazilian Journal of Information Systems) http://seer.unirio.br/index.php/isys/ 


\begin{tabular}{|c|l|}
\hline behavior & $\begin{array}{l}\text { citizens living in cities are intangible assets that must be considered when } \\
\text { planning, developing, and using digital services by stakeholders in smart cities } \\
\text { context. }\end{array}$ \\
\hline Information Flow & $\begin{array}{l}\text { Data, information and knowledge shared among stakeholders, including } \\
\text { transparency, security, confidentiality, and privacy requirements must be taken } \\
\text { into account by decision makers in municipalities in the context of digital and } \\
\text { intelligent transformation of cities. }\end{array}$ \\
\hline $\begin{array}{c}\text { People, Skills and } \\
\text { Competencies }\end{array}$ & $\begin{array}{l}\text { Human resources with developed skills and competences must be considered in } \\
\text { the development of smart city projects, so that it would be able to have qualified } \\
\text { professionals to assume distinctive positions, such as public policy makers, } \\
\text { conflict managers, risk and security practitioners, social media designers and } \\
\text { specialists in digital relationship channels in the context of cities smart } \\
\text { transformation. }\end{array}$ \\
\hline Service, Infrastructure, and \\
Applications & $\begin{array}{l}\text { Technological solutions, tools, applications, infrastructure and service levels must } \\
\text { be maintained by smart cities projects management to support and meet citizens' } \\
\text { needs, especially by adopting disruptive technologies to develop smart services. }\end{array}$ \\
\hline
\end{tabular}

\section{Source: [Reis et al. 2020b]}

These governance components act as drivers for structuring and implementing ICT governance practices and are generally represented by artifacts [ISACA 2012] [SISP 2017] [ISACA 2018]. With such components in perspective, a methodology for an ICT governance analysis in the context of Brazilian smart cities is presented below.

\section{Methodology}

This work represents an applied research once it covers a study that contributes to the expansion of scientific knowledge and issues to be investigated concerning the main subject [Lakatos \& Marconi 2006] [Gil 2010]. In relation to its objective, this is a descriptive research once it seeks for a greater familiarity with the investigated problem considering that there is little academic research related to the topic [Lakatos \& Marconi 2006] [Gil 2010]. This research is characterized as a qualitative study once it seeks to analyze data intuitively. In relation to its procedures, this is a bibliographic, documentary, and data collection research considering that it was based on the available information and documents [Lakatos \& Marconi 2006] [Gil 2010].

In this research, the methodological procedures were structured in five main phases, as shown in Figure 2.

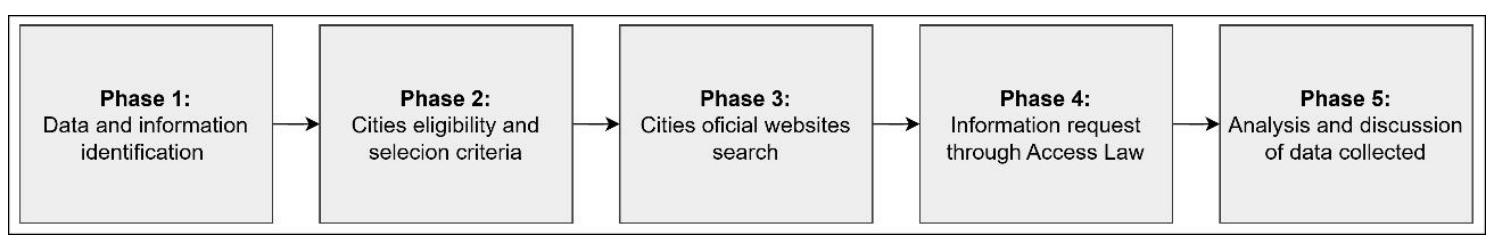

Figure 2. Research methodology phases

\section{Source: Elaborated by authors}

Based on the research objective and procedures, each methodology phase is described as follows.

\section{Phase 1: Data and information identification}

This step aimed to identify data and information required to evaluate ICT governance requisites in the context of Brazilian smart cities. The related information was identified by using the COBIT 2019 framework [ISACA 2012] [ISACA 2018] and the exploratory study conducted by [Reis et al. 2020b] as reference guidance. The result of this analysis 
is described in Table 2, which shows the list of sixteen information criteria eligible for evaluation in this study.

Table 2. Data and information required for the study

\begin{tabular}{|l|l|}
\hline ID & \multicolumn{1}{|c|}{ Data and information description } \\
\hline$\# 1$ & Smart city project, plan or similar document containing initiatives to transform the city into a smart one. \\
\hline$\# 2$ & ICT strategic plan and/or ICT master plan issued by the city. \\
\hline$\# 3$ & ICT risk management plan issued by the city. \\
\hline$\# 4$ & ICT investment plan issued by the city. \\
\hline$\# 5$ & ICT organizational structure issued by the city. \\
\hline$\# 6$ & List of the strategic projects describing their names, objectives, benefits, and monitoring actions. \\
\hline$\# 7$ & $\begin{array}{l}\text { List of ICT policies adopted by the city describing their names, guidelines, objectives and } \\
\text { responsibility. }\end{array}$ \\
\hline$\# 8$ & List of ICT committees in the city describing their names, objectives, competences, and composition. \\
\hline$\# 9$ & $\begin{array}{l}\text { List of channels/technological resources used by the city to engage the community in its digital } \\
\text { initiatives. }\end{array}$ \\
\hline$\# 10$ & $\begin{array}{l}\text { List of Public Private Partnerships (PPP), Local or International Agreements, either with governments } \\
\text { or specialized companies involving the use of ICT resources in the city. }\end{array}$ \\
\hline$\# 11$ & $\begin{array}{l}\text { ICT governance model adopted by the city, identifying ICT governance area responsibilities, people } \\
\text { involved, and the benefits expected with the model. }\end{array}$ \\
\hline$\# 12$ & $\begin{array}{l}\text { Plan or project adopted by the city focused on the privacy of citizens' personal data in reference to } \\
\text { LGPD. }\end{array}$ \\
\hline$\# 13$ & City's code of conduct/integrity guide that governs the use and handling of ICT resources by employees. \\
\hline$\# 14$ & Training plan for ICT practitioners in the city. \\
\hline$\# 15$ & Contract regulation document issued by the city and the list of ICT contracts. \\
\hline$\# 16$ & List of indicators issued by the city to measure the performance of ICT. \\
\hline
\end{tabular}

Source: Elaborated by authors from [ISACA 2018] [Reis et al. 2020] [Reis et al. 2020b]

These reference artifacts were used as baseline documents for analyzing ICT governance requirements and practices in the context of Brazilian smart cities.

\section{Phase 2: Cities eligibility and selection criteria}

Cities' selection was based on the 2020 Connected Smart Cities Ranking issued by Urban Systems obtained on 07/25/2020 [Connected Smart Cities, 2020]. This ranking collects data and information from Brazilian municipalities with more than 50 thousand inhabitants as estimated by IBGE [IBGE 2017]. The 2020 Urban System ranked 673 cities in three clusters: (i) 48 cities with more than 500 thousand inhabitants $(+500 \mathrm{k})$; 274 cities with 100 to 500 thousand inhabitants (100 a 500k); and 349 cities with 50 to 100 thousand inhabitants (50 a 100k).

This study analyzed forty-five municipalities best ranked in the Smart Cities Ranking distribute in all of the three clusters. Figure 3 shows the extended sampling process adopted in the study.

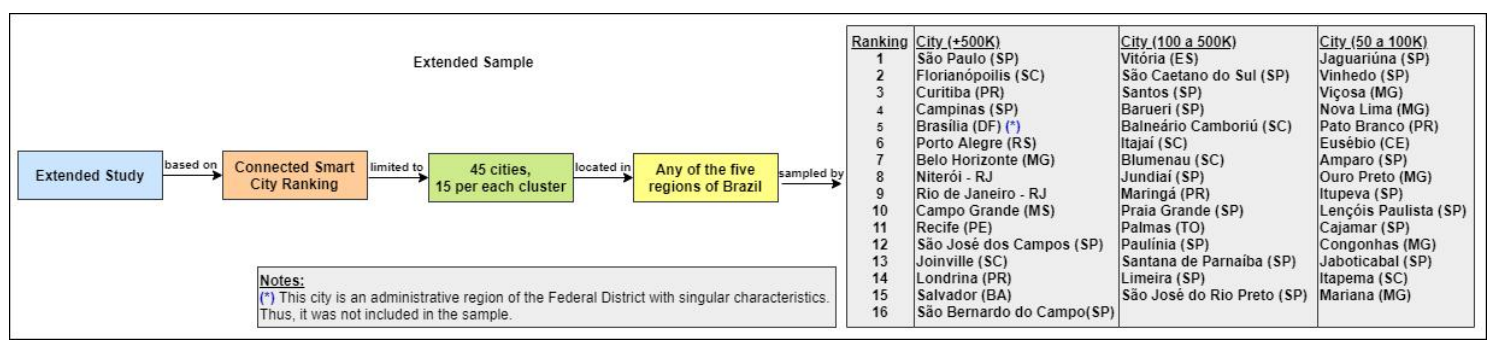

Figure 3: Cities sample process 


\section{Source: Elaborated by authors}

This sampling process excluded the capital Brasilia, in the 5th position of cities $(+500 \mathrm{k})$, because it is considered an administrative region of the Federal District, with unique administration characteristics. Thus, the city ranked in the $16^{\text {th }}$ (São Bernardo do Campo) was included in the sample. As described in Figure 3, the sample is composed of forty-five cities, in which fifteen cities were selected from each of the three clusters. This sampling process represents an extended study of previous researches [Reis et al., 2020] [Reis et al., 2020b] [Reis et al., 2021].

The motivation for adopting the Connected Smart Cities Ranking was twofold. First, this ranking mapped cities with greater development potential through 70 (seventy) indicators that portray the qualities for smart cities: intelligence, connection, and sustainability in eleven axes (Mobility and Accessibility, Urbanism, Environment, Education, Energy, Economy, Technology and Innovation, Health, Security, Entrepreneurship, and Governance). Second, there are no other official available rankings in Brazil that map cities in accordance to their smart initiatives or projects. Thus, based on the objective of this study, this ranking was the most appropriated to select cities to analyze ICT governance requisites in reference to smart city context.

\section{Phase 3: Cities official websites search}

This step involved analyzing whether the required information described in Table 2 was available on the official websites and the transparency portals of each municipality.

\section{Phase 4: Information request through Access Law}

This step consisted of requesting the information described in Table 2 from the cities based on the Access Information Law through their transparency portals using the e-SIC (Electronic Citizen Information Service) functionality [Brazil 2011].

\section{Phase 5: Analysis and discussion of data collected}

This step consisted of analyzing and consolidating the information retrieved from the cities' websites (Phase 3) and those obtained from the Access Law requests (Phase 4) from March to November 2020.

\section{Discussion of Results}

\subsection{Analysis of information requests}

It was not easy to identify all the information described in Table 2 on the official websites and the transparency portals of the municipalities. Thus, to avoid wrong interpretation of any information searched, it was decided to request all of them on the cities' transparency portal based on Information Access Law [Brazil 2011].

Among the forty-five information requests addressed to the cities, in 30 (thirty) the information requests were answered $(66,67 \%)$, in 13 (thirteen) the requests were not answered (28,89\%), and in 2 (two) there was not available an online information request functionality $(4,44 \%)$. Figure 4 shows these related numbers. 


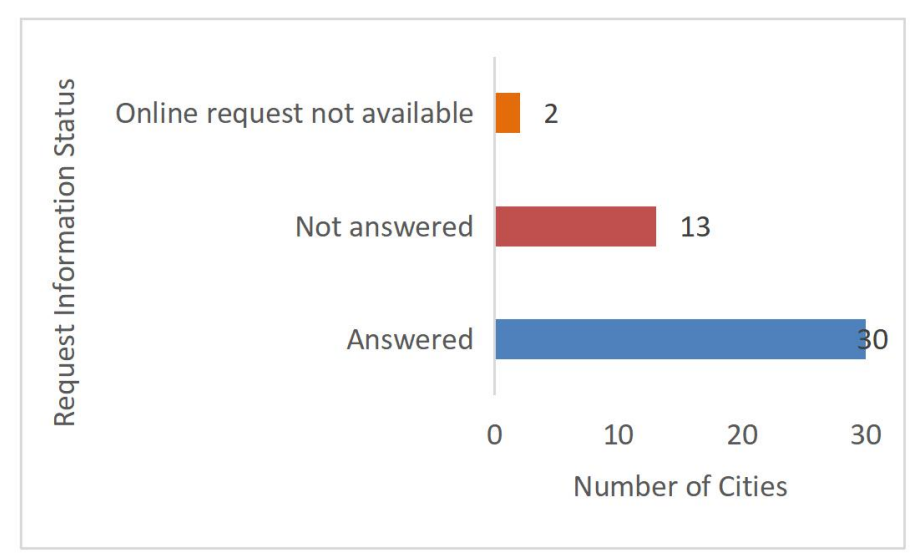

Figure 4. Status of information requests

\section{Source: Elaborated by authors}

Based on the cities that answered the information requests and on the fact that each request was composed of sixteen items, an individual request item varied from one of the following status: information/document available, document under development, document/information still in discussion, Information/document not available, or item not answered. By using this scheme, mixed with symbols and colored background, each information request/item addressed to cities was individualized by using the legend as shown in Table 5.

Table 5: Information request legend adopted in the study

\begin{tabular}{|c|c|}
\hline Symbol & Description \\
\hline & Request/item not answered \\
\hline $\boldsymbol{\otimes}$ & Online request not available \\
\hline $\boldsymbol{x}$ & Information not available \\
\hline$\checkmark$ & Information available \\
\hline$\varnothing$ & Document under development \\
\hline$\odot$ & Document still in discussion \\
\hline
\end{tabular}

With this scheme on perspective, the information requests addressed to each city were individualized, as shown in Table 6.

Table 6. Information requests status addressed to cities 


\begin{tabular}{|c|c|c|c|c|c|c|c|c|c|c|c|c|c|c|c|c|c|}
\hline 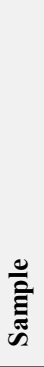 & 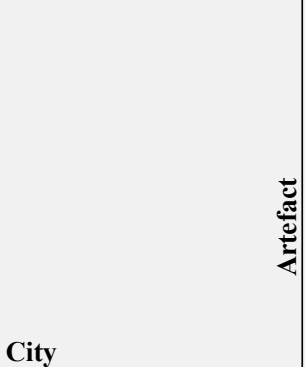 & 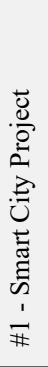 & 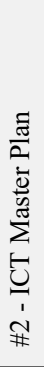 & 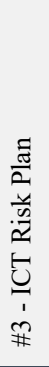 & 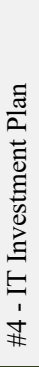 & 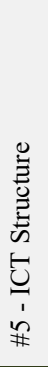 & 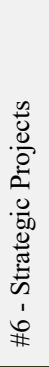 & 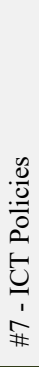 & 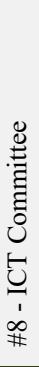 & 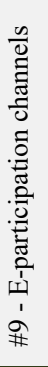 & 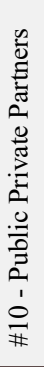 & 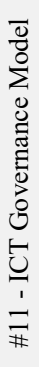 & 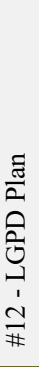 & 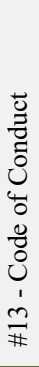 & 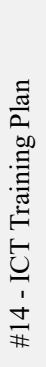 & 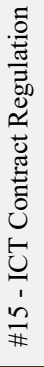 & 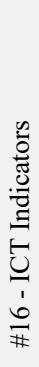 \\
\hline \multirow{15}{*}{ 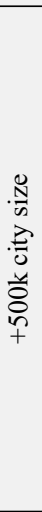 } & São Paulo & $x$ & $\checkmark$ & ;) & $\checkmark$ & $\sqrt{ }$ & $\checkmark$ & $\sqrt{ }$ & $\sqrt{ }$ & $\checkmark$ & $x$ & $\sqrt{ }$ & 25 & es & $\sqrt{ }$ & $\checkmark$ & $\checkmark$ \\
\hline & Florianópolis & 8 & 8 & 8 & 8 & 8 & 8 & 8 & 8 & 8 & 8 & 8 & 8 & 8 & 8 & 8 & 8 \\
\hline & Curitiba & $x$ & $\checkmark$ & $x$ & $\checkmark$ & $\checkmark$ & $\checkmark$ & $\checkmark$ & $\checkmark$ & $\checkmark$ & 8 & $\checkmark$ & es & $x$ & $x$ & $\checkmark$ & $x$ \\
\hline & Campinas & $\checkmark$ & $\checkmark$ & 8 & 8 & 8 & $x$ & 9 & $\checkmark$ & $\checkmark$ & $x$ & 8 & es & 8 & 8 & 8 & 8 \\
\hline & Porto Alegre & 8 & es & $x$ & $x$ & $\checkmark$ & $\checkmark$ & $\checkmark$ & $\checkmark$ & $\checkmark$ & $x$ & es & es & $\checkmark$ & 8 & $\checkmark$ & $x$ \\
\hline & Belo Horizonte & :) & $x$ & $x$ & $\checkmark$ & $\checkmark$ & $\checkmark$ & $\checkmark$ & $\checkmark$ & $\checkmark$ & $\checkmark$ & $\checkmark$ & es & $\checkmark$ & $\checkmark$ & $\checkmark$ & $\checkmark$ \\
\hline & Niterói & $\checkmark$ & $x$ & $x$ & $x$ & $x$ & 8 & $x$ & $\checkmark$ & 8 & $x$ & $x$ & $x$ & $x$ & $x$ & $\checkmark$ & $x$ \\
\hline & Rio de Janeiro & $\checkmark$ & $x$ & $\checkmark$ & $\checkmark$ & 8 & 8 & $\checkmark$ & $\checkmark$ & $\checkmark$ & 8 & $\checkmark$ & $x$ & $\checkmark$ & $\checkmark$ & $\checkmark$ & $\checkmark$ \\
\hline & Campo Grande & es & 25 & $x$ & $\checkmark$ & $\checkmark$ & $x$ & $\checkmark$ & $x$ & $\checkmark$ & $\checkmark$ & $x$ & es & $\checkmark$ & $\checkmark$ & $\checkmark$ & $\checkmark$ \\
\hline & Recife & $\checkmark$ & $\checkmark$ & (:) & $\checkmark$ & $\checkmark$ & $\checkmark$ & $\sqrt{ }$ & $\checkmark$ & $\checkmark$ & 8 & $\sqrt{ }$ & es & $\checkmark$ & 8 & $\checkmark$ & $\checkmark$ \\
\hline & São José dos Campos & 目 & 目 & 可 & 可 & 目 & 国 & 田 & 可 & 田 & 可 & 田 & 可 & 田 & 田 & 田 & 冈 \\
\hline & Joinville & 8 & $x$ & $x$ & $x$ & $\checkmark$ & 8 & $\sqrt{\checkmark}$ & $\sqrt{\checkmark}$ & $\sqrt{\checkmark}$ & $\sqrt{\checkmark}$ & $x$ & 25 & $\bar{\checkmark}$ & $x$ & $\sqrt{\checkmark}$ & $x$ \\
\hline & Londrina & 2 & 2 & $\checkmark$ & $\checkmark$ & $\checkmark$ & $\checkmark$ & $\checkmark$ & $\checkmark$ & $\checkmark$ & $\checkmark$ & es & es & $\checkmark$ & $x$ & $\checkmark$ & $\checkmark$ \\
\hline & Salvador & 8 & 2 & 8 & 8 & 8 & 8 & 25 & 8 & 8 & $x$ & es & 8 & 8 & 8 & 8 & es \\
\hline & São Bernardo do Campo & es & ;) & $x$ & $x$ & $x$ & $x$ & $x$ & $x$ & $x$ & $\sqrt{ }$ & $x$ & (-) & $x$ & $x$ & $\sqrt{ }$ & $x$ \\
\hline \multirow{15}{*}{ 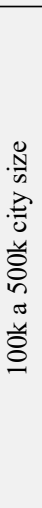 } & Vitória & 8 & 8 & P & 8 & 8 & P & P & P & P & 8 & 8 & 8 & P & 8 & 8 & 8 \\
\hline & São Caetano do Sul & $x$ & Es & es & Es & $\checkmark$ & $x$ & es & $x$ & $\checkmark$ & $\checkmark$ & es & 25 & 25 & $x$ & $\checkmark$ & 2 \\
\hline & Santos & $x$ & $\checkmark$ & $x$ & 8 & $\checkmark$ & 8 & $x$ & 8 & 8 & $\checkmark$ & $x$ & (-) & $\sqrt{ }$ & $x$ & $\checkmark$ & $\checkmark$ \\
\hline & Barueri & $\checkmark$ & 8 & $x$ & 8 & $x$ & 8 & $x$ & $x$ & $\checkmark$ & $x$ & $x$ & es & $\checkmark$ & $x$ & $x$ & $x$ \\
\hline & Balneário Camboriú & 8 & 8 & P & 8 & 8 & 9 & $\checkmark$ & $\beta$ & $\checkmark$ & 8 & 8 & 8 & 8 & 8 & 8 & $\checkmark$ \\
\hline & Itajaí & (-) & 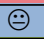 & $\ddot{\theta}$ & $\ddot{\theta}$ & $\checkmark$ & (-) & (-) & 8 & $\checkmark$ & $x$ & 8 & 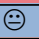 & 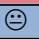 & (-) & $\checkmark$ & $\checkmark$ \\
\hline & Blumenau & $\checkmark$ & $\checkmark$ & $x$ & $\checkmark$ & $\checkmark$ & $\checkmark$ & $x$ & $x$ & $\checkmark$ & $x$ & $x$ & $x$ & $x$ & $\checkmark$ & $\checkmark$ & $\checkmark$ \\
\hline & Jundiaí & $\checkmark$ & $x$ & $x$ & $\checkmark$ & $\checkmark$ & $\checkmark$ & $\checkmark$ & $\checkmark$ & $\checkmark$ & $x$ & $x$ & es & $\checkmark$ & $\checkmark$ & $\checkmark$ & $\checkmark$ \\
\hline & Maringá & 8 & 8 & 8 & 8 & 8 & 8 & 8 & 8 & 8 & 8 & 8 & 8 & 8 & 8 & 8 & 8 \\
\hline & Praia Grande & 8 & 8 & 8 & 8 & 8 & 8 & 8 & 8 & 8 & 8 & 8 & 8 & 8 & 8 & 8 & 8 \\
\hline & Palmas & 2 & 2 & 25 & es & 25 & 2 & 2 & 25 & es & 25 & es & 2 & 2 & es & es & $\mathscr{L S}$ \\
\hline & Paulínia & 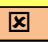 & $\nabla$ & 国 & 目 & 目 & 国 & 冈 & 可 & 可 & 可 & 田 & 国 & 国 & 田 & 国 & 冈 \\
\hline & Santana de Parnaíba & $\checkmark$ & $\checkmark$ & $x$ & $\checkmark$ & $\checkmark$ & $\checkmark$ & $\checkmark$ & $x$ & $\checkmark$ & $x$ & es & 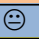 & $\checkmark$ & $\checkmark$ & $\checkmark$ & es \\
\hline & Limeira & $x$ & 2 & es & $\checkmark$ & $\checkmark$ & P & es & $x$ & $\checkmark$ & $\sqrt{\checkmark}$ & $x$ & es & es & $x$ & $x$ & $\sqrt{ }$ \\
\hline & São José do Rio Preto & $\checkmark$ & $\checkmark$ & (-) & $\checkmark$ & $\checkmark$ & $\checkmark$ & $\checkmark$ & $\checkmark$ & $\checkmark$ & $\checkmark$ & $\checkmark$ & $\sqrt{ }$ & $\sqrt{ }$ & $\mathbb{E}$ & $\checkmark$ & $\checkmark$ \\
\hline \multirow{15}{*}{ 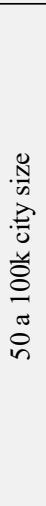 } & Jaguariúna & 8 & 8 & 8 & 8 & 8 & 8 & 8 & 8 & 8 & 8 & 8 & 8 & 8 & 8 & 8 & 8 \\
\hline & Vinhedo & $x$ & $\checkmark$ & es & $x$ & $x$ & $x$ & $\checkmark$ & $\checkmark$ & $\checkmark$ & $x$ & $x$ & es & 25 & $x$ & $\checkmark$ & $x$ \\
\hline & Viçosa & $\checkmark$ & 25 & es & es & 2 & $\dot{\theta}$ & 2 & $x$ & 8 & $x$ & es & (-) & $\dot{\theta}$ & $x$ & 8 & es \\
\hline & Nova Lima & $x$ & es & es & es & $\checkmark$ & $x$ & $\checkmark$ & $x$ & $\checkmark$ & 8 & es & 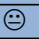 & $\checkmark$ & es & $\checkmark$ & $x$ \\
\hline & Pato Branco & $\checkmark$ & $x$ & $x$ & $x$ & $x$ & $x$ & $x$ & $x$ & $x$ & $x$ & $x$ & $x$ & $x$ & $x$ & $x$ & $x$ \\
\hline & Eusébio & 8 & 8 & 8 & 8 & 8 & 8 & 8 & 8 & 8 & 8 & 8 & 8 & 8 & 8 & 8 & 8 \\
\hline & Amparo & 8 & 8 & 8 & 8 & 8 & 8 & 8 & 8 & 8 & 8 & 8 & 8 & 8 & 8 & 8 & 8 \\
\hline & Ouro Preto & 8 & 8 & 8 & 8 & 8 & 8 & 8 & 8 & 8 & 8 & 8 & 8 & 8 & 8 & 8 & 8 \\
\hline & Itupeva & $x$ & $x$ & $x$ & $x$ & $x$ & $x$ & $x$ & $x$ & $x$ & $x$ & $x$ & $x$ & $x$ & $x$ & $x$ & $x$ \\
\hline & Lencóis Paulista & 8 & 8 & 8 & 8 & 8 & 8 & 8 & 8 & 8 & 8 & 4 & 8 & 8 & 8 & 8 & 8 \\
\hline & Cajamar & 2 & 25 & $\dot{\theta}$ & 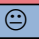 & $\dot{\theta}$ & 8 & 25 & $\dot{\theta}$ & es & 8 & $\dot{\theta}$ & 25 & $\dot{\theta}$ & 2 & ;) & 2 \\
\hline & Congonhas & 8 & 8 & 8 & 8 & 8 & 8 & 8 & 8 & 8 & 8 & 8 & 8 & 8 & 8 & 8 & 8 \\
\hline & Jaboticabal & 8 & 8 & 8 & 8 & 8 & 8 & 8 & 8 & 8 & 8 & 8 & 8 & 8 & 8 & 8 & 8 \\
\hline & Itapema & 8 & 8 & 8 & 8 & 8 & 8 & 8 & 8 & 8 & 8 & 8 & 8 & 8 & 8 & 8 & 8 \\
\hline & Mariana & 8 & 8 & 8 & 8 & 8 & 8 & 8 & 8 & 8 & 8 & 8 & 8 & 8 & 5 & 8 & 8 \\
\hline
\end{tabular}

The cities that did not answer the information requests were Florianópolis, Vitória, Maringá, Praia Grande, Jaguariúna, Eusébio, Amparo, Ouro Preto, Lençóis Paulista, Congonhas, Jaboticabal, Itapema, and Mariana. Congonhas asked to get in contact with the IT department to obtain the related information. Joboticabal opened an administrative process to answer the request, whereas Praia Grande and Florianópolis informed that the request should be done by e-mail. Itupeva pointed out that the IT Department is under reconstruction for better organization, operation and development of projects, and that the city is bidding a specialized company to develop its IT Master Plan to establish goals and necessary investments to the area. Palmas reported that its Municipal Information Technology Agency was created in 2018 and that most of the requested information are under developed by the company and suggests to be in contact by e-mail. Maringá, Praia Grande, Jaguariúna, Eusébio, Amparo, Ouro Preto, Lençóis Paulista, Itapema did not reply the request, which is still open. Vitória 
postponed the request twice and commented that due to cybersecurity attacks, some website functionalities were unable to return to normal access.

São Jose dos Campos and Paulínia do not have an online functionality for information requests on their transparency portal. The website of São José dos Campos informs that information requests should be done only presently by filling a form, even though, some of the requested information were identified at its website.

Based on these results, the cities' procedures were not in compliance with the Information Access Law because they did not meet legal requirements [Brasil 2011]. Some cities exceeded the law response time, and others closed the information requests inappropriately, not answering them. Thus, these cities were unable to provide the information/documents requested by the Access Information Law. Also, most of them did not actively make available the related information on their websites or transparency portals. Considering that transparency is part of smart cities' requisites and principles, these cities did not meet this fundamental requirement. The other thirty-three cities answered the requests, but none of them presented the complete information; neither it was available on the websites. The next section analyses the information content received from the cities and those searched on their websites or transparency portals.

\subsection{Analysis of data collected}

In relation to "\#1 - Smart City Plan", fourteen cities presented a smart city project, plan or initiatives, six cities informed that the plan is under development, and two cities reported that the plan is still in discussion. Based on the available documents, the cities are engaged in smart initiatives concerning learning environments, startup program, citizen integration, collaborative platform, intelligent mobile services, security, energy, LED street lighting and operation integrated control management. Campo Grande and Belo Horizonte informed about a law proposal that is under analysis concerning their smart cities programs, whereas the other cities did not inform about specific legislation covering this theme. Curitiba did not present a smart city project, but several actions for smart cities initiatives are described in the city ICT Master Plan. Campinas Municipal ICT Council developed a Smart City Strategic Master Plan with several initiatives to be appreciated by the city legislative function. In Vitória website, there is a Technology Master Plan for Smart Cities elaborated by the Smart Cities Business America Institute, although there is no evidence it was approved by the Executive and Legislative. São Paulo informed that a smart and human city project was built in 2019, but it did not continue in the current government cycle.

Based on this analysis, few cities provided a smart city project or plan formalization. In most of cities, the smart city projects are decentralized and managed by each city's secretariat, which makes governance a challenge. Few cities issued a municipal legislation about transforming cities into smart ones. These results evidenced that smart cities process in Brazil is still at an initial time, and certainly, there is much work to do in the near future in the cities, especially in small and medium cities to adopt an effective smart city program to transform the smartness of the cities.

In relation to "\#2 - ICT Master Plan" encompassing both the Strategic Plan (PETIC) and the Director Plan (PDTIC), nine cities presented at least one of them and in thirteen cities these documents are under development. São Paulo was the unique city that presented the Strategic Plan, the General ICT Director Plan (PDGTIC), and the

iSys: Revista Brasileira de Sistemas de Informação (isys: Brazilian Journal of Information Systems) 
cities Sectorial Plans (PDTICSEC), artefacts that reflect each city secretariat activities are in alignment with city's main plans. The city of Campinas developed the Smart Cities Information Technology Master Plan (PDTCI) and the Strategic Planning of Technology and Innovation Science and highlights that solutions for smart cities must be defined from a broad view of demand. Curitiba, Recife, Blumenau, Santos, and Santana de Parnaíba presented their PDTIC. Joinville informed that there is no PDTI in place, however, the actions that are being carried out are in line with recommended public management and Information Technology good practices. These plans, independent of their denomination, are essential and work as a starting point for cities that are engaged in a governance structure for smart cities initiatives, in which IT strategy planning and execution must be part of cities management environment to achieve cities strategy and objectives and citizen's needs. In some cities, these artefacts are formally referenced in a Decree regulation, which makes them as a priority in those municipalities. The low result concerning this information criteria evidenced that cities need to make strategic effort to build ICT plans as guidelines to reach an effective smart city environment.

In relation to "\#3 - ICT Risk Plan", Rio de Janeiro was the unique city that provided this artefact, which is based on operational IT risk management. This city has a strategy goal to reduce IT risks concerns up to $30 \%$. Londrina informed that the city introduced an IT risk approach on ICT procurement contract solutions, based on Federal Normative Instruction $n^{\circ} 1 / 2019$. In six cities this artefact is under development and in five it is still in discussion. São Paulo informed that risk management concerns are in discussion to be part of its future Municipal Information Security Policy. Based on the results, except of Rio de Janeiro, cities are not prioritizing IT risk in the context of smart city. This scenario demonstrates that risk practices are not internalized in cities management organizational environment. From a COBIT 2019 governance perspective, risk management works as a driver for governance in the triad GRC (Governance, Risk and Compliance), especially in complex environments such as cities.

In relation to "\#4 - IT Investment Plan", fourteen cities informed that the IT investment plan is instituted together, along with the city annual planning, while defining its Annual Budget Law (LOA). In four cities IT investment plan initiatives are underdeveloped for the next circle, and in one city it is still in discussion. The cities informed that the IT investment process is not centralized, and its budget is derived from LOA. Considering that Information Technology (IT) is a smart city enabler, cities must implement good practices towards ICT costs and investment mechanisms along with IT strategy related to each secretariat units to achieve return on investments and benefits achievement in reference to municipal public policies.

In relation to "\#5 - ICT Structure", nineteen cities presented their organizational structure, two cities reported that it is under development, and another one answered that the IT structure is still in discussion. Most cities informed that the IT functions are not centralized and that IT permeates each city secretariats, in which IT process management becomes a more complex and challenging for city leaders. Recife reported that a public enterprise is responsible for IT functions with its professionals to provide IT services for the municipality. IT unit management varies from city to city, which depends on their internal organizational structure. This study revealed that cities ' IT structure can be represented by an IT municipal secretariat, an IT department in a government or management secretariat, a sectorial administrative unit in a secretariat, a 
public municipal company responsibility; or none IT-related unit in the city. IT activities are segmented and decentralized in the municipalities and each secretariat is responsible for its information management and policy actions. This scenario evidenced that cities are different from one to another but, from a public governance perspective, cities as municipal administrative entities should not transfer governance responsibilities to a third party; even if IT is decentralized, the governance process should be guided by city senior management. Thus, a Governance Office (GO) should be a good practice for structuring and managing ICT governance in cities, especially from a smart city perspective.

In relation to "\#6 - Strategic Projects", seventeen cities presented a list of priority projects included in cities strategy, in one city it is under development, and in two cities the projects are still in discussion. Although these projects should be integrated into the City Pluriannual Plan, few cities demonstrated that they monitor them. Annually, while elaborating the Annual Accountability Report, cities put this procedure in place. The cities low maturity in project management was stated by several cities, which reflects a low accomplishment with this information issue. Most cities identified their strategic projects, but few of them control and monitor them. As stated before, a project office should be a good practice for cities to transform their smartness.

In relation to "\#7 - ICT Policies", eighteen cities presented at least one related policy. These policies vary from General ICT Policy, Governance, Information Security, Computer Use, Resource Use, or Quality Management. São Paulo, Curitiba, Belo Horizonte, and São José dos Campos established a Municipal ICT Policy through a decree. These cities' policies also encompass an ICT governance perspective. From a smart city perspective, cities should establish policies that reflect management guidelines towards ICT. A policy is a document that defines the high-level strategies that represent the basic principles that the municipal management decided to incorporate into its ICT environment and it works as a guidance for elaborating rules and procedures related to the use, adoption, and management of ICT. From a COBIT 2019 perspective, this information criteria evaluation was in a low maturity process because few ICT policies are effectively implemented in cities and some of them need to be reviewed in accordance to corporate governance practices.

In relation to "\#8 - ICT Committee", fourteen cities informed that they have a formalized committee or council in the city. The committee's nomination varied from several terminologies, such as Strategic Information and Communication Technology Committee (CETIC); Governance 4.0 Committee; Municipal Committee for Information, Communication and Geoprocessing Technologies (CTIC); Strategic Information Technology Committee (CETI); Municipal ICT Council (CMTIC); and Municipal Council for Science, Technology and Innovation (CMCTI). The cities committee structure was composed of secretariats from different areas and, when applicable, a member of an ICT company from the indirect administration participates. The city committees have deliberative and consultant roles, except for the councils which roles are exclusively advisory, as evidenced in Campinas, but its structure is not adequate for the city's needs, as evidenced by its members in available documents. Recife and Campo Grande attributed the governance duties to their informatics companies as part of the indirect administration from the municipalities, but this approach is not aligned with public governance frameworks. Belo Horizonte established a Health Information Technology Management Committee (CGTIS), specific for health 
initiatives. Porto Alegre Municipal Council of Science and Technology (COMCET) last decision took place in 2015, as evidenced in its website. In a general sense, committees represent municipal instances with the purpose to evaluate technology needs and usage for the cities, under business needs. Thus, a committee should track technology progress and prioritize initiatives, make decisions on projects, identify training needs, budget, and overall IT forecast. The approval of policies, governance, and security concerns, and innovative approaches should be some responsibilities of committees. Several cities need to review their committees' structure and effectiveness, for instance, Rio de Janeiro has four committees in place related to technology and innovation. Also, an open ICT governance approach should be the focus of the cities to reach smartness in governance.

In relation to "\#9 - E-participation channels", twenty-five cities answered the request and provided information about it, one city reported that e-channels are under development, and one city informed that e-channels are still under discussion. For the cities that did not answer the request, it was able to identify that they apply digital echannels initiatives by searching the information on the websites. Thus, this information criteria were the one with a positive return. Most cities' e-channels are related to mobile applications services, internet websites, social media resources, transparency portals, chatbots, and other applications used to engage citizens in the city. The e-channels user's experience, usability, accessibility, and related unfunctional requisites were not in the scope of this study.

In relation to "\#10 - Public-Private Partners (PPP)", nine cities informed that they have a formal PPP contract, but some of the cities considered a government partner contract in their answer. São Bernardo issued a public lightning contract in which all the related information is available on its website. Some cities informed that the PPP contracts are available at their transparency portals. Blumenau issued a committee for public-private partner relationships, even though there is no PPP contract formalized in the city. Based on the city's answers, PPP is still at the beginning in Brazilian cities compared to European cities' implementation. There is much to be done in this respect, especially by improving rules and regulations about this topic. Most cities reported that PPP is important because municipalities need support from private sectors and the academia to implement new applications and services based on emerging technologies in a smart city context.

In relation to "\#11 - ICT Governance Model", six cities informed that they have this artifact, nine answered that it is under development, and one it is still in discussion. São Paulo, Curitiba, Belo Horizonte, and São José dos Campos through their Municipal ICT Policies, established an ICT governance structure based on the delimitation of tasks, duties, and responsibilities for each entity and representative as part of the governance system; legal and technical standards. Porto Alegre's governance model is based on a Strategic Management System structured on three pillars: (i) Strategy: Promotion of deliveries through structuring projects, (ii) Governance Network: Centralized management at SMPG, and (iii) Systemic Monitoring: translation of the strategy into deliveries. Rio de Janeiro informed that the ICT Governance Model is based on COBIT 4.1 and ISO 38500, with the technical support of the IPLAN Company in its implementation. Although Salvador issued a decree establishing an ICT Policy, the related regulation states that the policy document is published on a website, but the document is not available and it still under development based on the E-sic response. Recife, Campo Grande, and São José do Rio Preto attributed governance competencies 
to a third party, represented by their IT public companies EMPREL, AGETEC, and EMPRO, respectively. On the other hand, Belo Horizonte makes explicit that The Corporate Governance guidelines and criteria must be followed by mixed capital companies and other companies controlled directly or indirectly by the Municipality. Cities reported about their challenges and difficulties in governing and managing ICT considering that this activity is decentralized in the city and there is not a body responsible for it in city structure. Curitiba and São José dos Campos governance focus areas are identified, so that the related processes can be governed by a central body.

In relation to "\#12 - LGPD Plan", nineteen cities answered that there are ongoing initiatives related to this privacy legislation and in six cities this process is still in discussion. Joinville answered that the LGPD is implemented with service providers, however, it is necessary to adopt measures regarding data management, collection, and storage for the whole municipality. São Paulo, Curitiba, Campinas, Porto Alegre, São José dos Campos, Londrina, and Jundiaí established a Working Group by Decree to establish actions for LGPD adoption and to be compliant with the law requirements. Porto Alegre established a Data Protection Management Committee and Belo Horizonte instituted a web portal and provided a booklet about this law. The LGPD law has been in operation since September 2020 in Brazil, however, the penalties and fines provided by the decree will only be applied from August 2021. In the context of smart cities, citizens' privacy is a concern that cities must deal with. Thus, the objective of this investigation was to make a diagnosis of how cities are reacting towards this law, especially because its operation is challenging and there is much work to do to be compliant with the law.

In relation to "\#13 - Code of Conduct", fourteen cities presented a code of conduct, seven cities informed that it is under development, and three cities related that it is still in discussion. Some cities instituted the code of conduct along with the Information Security Policy or with the IT Resources Use and Management Policy. São Paulo informed that there is a working group to elaborate the Municipal Information Security Policy that will include the awareness of ICT resources use. Rio de Janeiro was the unique municipality that provided an integrity initiative by establishing a Public Integrity System and a Compliance System related to code of conduct. This procedure reinforces city's commitment towards a responsible and integrity use of ICT resources and it is an important issue for smart cities from a leaning and creative environment. A digital smart city environment requires that the use of IT resources should be aligned with ethical concerns, including citizens and data protection towards integrity, confidentiality, and privacy among ICT users.

In relation to "\#14 - ICT Training Plan", seven cities informed that they have a formal plan, four cities informed that the plan is under development, and one city informed that the plan is still in discussion. São Paulo reported that there is a training program for continuing education of municipal employees in the ICT area and that the city reinforces that each sectoral body is encouraged to introduce training actions in their ICT Sectoral Master Plans. The cites of São Caetano do Sul, Limeira, Londrina, Joinville, and Curitiba did not present a formal or pre-established plan, but they informed that training is done in accordance to projects implementation, at distance learning, derived from new technologies or carried out by demand. In a smart city context, literacy and knowledge must be part of the city's environment towards emerging technologies, especially concerning learning and creative cities. Considering 
that IT knowledge is fundamental for smart cities implementation, city IT leaders and practitioners must be updated with this kind of knowledge and incorporate knowledge management practices in their daily activities.

In relation to "\#15 - ICT Contract Regulation", twenty-four cities informed about following a contract regulation based on federal laws or municipal regulations. Some cities have institutionalized their own regulatory program and procedures based on public law and regulation for contracts and supplier management. This item request was the one with the most positive response and with more maturity compared with the others. This is because this kind of information was instituted as an active transparency information procedure and implemented by cities at their transparency portals, based on contracts of all kinds.

In relation to "\#16 - ICT Indicators", fifteen cities presented a list of indicators applied to IT, which vary from strategic and operational measures, and most of them are associated with project management execution, as mentioned in Request Information \#6. Some cities monitor their projects annually through their Annually Report as a means of accountability. São Paulo adopted a maturity scale index as a mean to evaluate each IT area in alignment with its Strategic Planning. Porto Alegre reported that project management is a challenging activity in the city. The city if Santos reported a portfolio indicator concerning strategic and operational indicators. ICT governance management in cities' performance should be guided by indicators and metrics to evaluate the achievement of organizational benefits and results for public policy implementation.

\subsection{Analyses based on governance components system}

In this section the information requests were analyzed in the lights of COBIT 2019 framework based on governance components systems for smart cities [ISACA 2018][Reis et al, 2020b], as shown in Table 7.

Table 7. Information analysis based on governance components systems

\begin{tabular}{|c|c|}
\hline Component & Analysis \\
\hline $\begin{array}{c}\text { Principles, Frameworks, and } \\
\text { Models }\end{array}$ & $\begin{array}{l}\text { This component reinforces that cities must be guided by principles, politics (\#7 ICT Policies), } \\
\text { and models (\#11 ICT Governance Model) to be compliant with ICT governance requisites. } \\
\text { These components work as drivers for cities' governance guidance. ICT principles represent a } \\
\text { set of strategic statements on how ICT should be used in cities, whereas ICT policies } \\
\text { represent a set of objectives and guidelines to align strategic actions and ICT resources use in } \\
\text { cities. In the context of smart cities, policies must promote digital citizenship through } \\
\text { government transparency actions, an increase of electronic services, and an effective } \\
\text { municipal public management process. An ICT governance model represents a conceptual } \\
\text { basis of how ICT is managed, decisions are taken, strategic alignment is promoted, resources } \\
\text { are prioritized, projects are approved and monitored, value is delivered, investments are } \\
\text { allocated, and performance is established. In this study, São Paulo, Curitiba, Rio de Janeiro, } \\
\text { Belo Horizonte, and São José do Rio Preto cities are ahead in this topic considering that they } \\
\text { issued a decree upon this topic. On the other hand, Recife and Campo Grande, ICT } \\
\text { governance statements were delegated to third-parties' responsibilities. In medium and small } \\
\text { cities, this ICT governance component was poorly conceived and implemented. These } \\
\text { concerns should be topics for future investigation. }\end{array}$ \\
\hline Internal Processes & $\begin{array}{l}\text { To meet the objectives of the City Multiannual Plan and the Government Plan, cities can } \\
\text { implement an IT process-based approach to perform related tasks and activities. A process } \\
\text { approach represents an activity that converts inputs into outputs. Thus, by using a process- } \\
\text { based approach cities practitioners can make sure each process delivers outputs to the next } \\
\text { process and works aligned towards achieving a common goal. In this study, the artefacts (\#2 } \\
\text { ICT Master Plan, \#3 ICT Risk Plan, \#4 IT Investment Plan, \#6 Strategic Projects, and \#15 } \\
\text { ICT Contract Management) were applied as process good practices outputs. The Master Plan, } \\
\text { represented by the PETIC and the PDTIC, are instruments for setting municipal strategies to } \\
\text { conduct their institutional strategy planning. São Paulo was the unique city that presented } \\
\text { both ICT Strategic Plan (PETIC) and the General ICT Master Plan (PDGTIC). Rio de Janeiro } \\
\text { was the only city that provided an ICT Risk Management Plan, but it was considered mainly } \\
\text { conceptual and did not mention the city areas, processes or services involved. Most cities }\end{array}$ \\
\hline
\end{tabular}




\begin{tabular}{|c|c|}
\hline & $\begin{array}{l}\text { presented their ICT Strategic Plan (PETIC), but not the PDTIC, which is an operational } \\
\text { instrument to implement the PETIC. Niteroi, Limeira, and Rio de Janeiro informed that ICT } \\
\text { management is not centralized, which makes ICT governance a challenge for the cities. Most } \\
\text { cities informed that they applied a structure contract management based on rules and } \\
\text { regulations which represents a good practice in the management of ICT contracts and } \\
\text { services related to the acquisition of solutions and suppliers. Most cities implemented an ICT } \\
\text { investment plan aligned with the city Plan, although IT investments in cites plan are not } \\
\text { segregated from the LOA. Few cities demonstrated a project management approach, which is } \\
\text { important to guarantee that the City Plan will be reached. In the context of smart cities } \\
\text { proposed by [Gil-Gárcia et al. 2015], an ICT integration process perspective helps cities to } \\
\text { achieve their strategic objectives through governance mechanisms. Cities should also } \\
\text { structure a process approach in line with their strategic objectives, including purposes, } \\
\text { standards and goals. }\end{array}$ \\
\hline Organization Structure & $\begin{array}{l}\text { This component suggests that cities are organized in areas and in representative groups of } \\
\text { professionals with attributed duties and responsibilities. Thus, cities should define an ICT } \\
\text { structure to guarantee that activities are in place in accordance with the number of necessary } \\
\text { people, responsibilities, and tasks. According to [Weill and Broadbent 2000], it represents a } \\
\text { challenge to structure ICT governance based on an organization structure, considering } \\
\text { processes dimensions, practices workplace, and cultural environment direct influence } \\
\text { effective environmental management. In this study, this component encompasses IT structure } \\
\text { (\#5 ICT Structure) and committee (\#8 ICT Committee). Several cities structured committees } \\
\text { in their decision process, composed of consultative (technical) and deliberative (managers) } \\
\text { members, whereas in others, there are no committees; and others attributed this responsibility } \\
\text { to a third party. Several cities evidenced a structured ICT governance composition, but others } \\
\text { informed about the difficulties to organize ICT management in their environment based on } \\
\text { the fact that management is decentralized and disperse in city structure. From smart cities } \\
\text { perspective, an organizational structure can assist in the design of guidelines, strategic } \\
\text { planning, policies, rules, principles, and ICT related procedures to provide an adequate } \\
\text { administrative level. }\end{array}$ \\
\hline Culture, ethics and behavior & $\begin{array}{l}\text { This component was based on cities code of conduct (\#13 Code of Conduct) as an instrument } \\
\text { to guide ICT practitioners and other professionals in the cities. A code of conduct is a set of } \\
\text { rules for employees to protect business and services and it informs employees about } \\
\text { municipal expectations. A code of conduct represents a set of norms, rules, and } \\
\text { responsibilities or proper practices of an individual party or an organization towards ICT use } \\
\text { [ACC 2016]. From a smart city perspective, this governance component covers culture, } \\
\text { ethics, and behavior of citizens and ICT professionals, requirements to be considered when } \\
\text { planning and developing ICT services. Simply requiring members to read the code is not } \\
\text { enough to ensure that they understand it and will remember its contents [ACC 2016]. In this } \\
\text { study, few cities provided an ICT code of conduct. Future works can evaluate the } \\
\text { effectiveness of the code of conduct in the cities that provided one. }\end{array}$ \\
\hline Information Flow & $\begin{array}{l}\text { Information flow is a component that reflects how information is treated in cities within their } \\
\text { related parties. In this study, this component is composed of privacy concerns (\#12 LGPD } \\
\text { Plan) and partnership agreement (\#10 Public-Private Partners). Several cities informed that } \\
\text { they have projects under development concerning the requirements of LGPD - General } \\
\text { Personal Data Privacy Law [Brazil } 2018 \text { b]. This law is in place, but its penalty will start in } \\
\text { August } 2021 \text {. In this study, the cities were mapped about their situation towards LGPD, and } \\
\text { we can conclude that several cities are making efforts to implement the law requisites; } \\
\text { whereas others did not start the process. Privacy represents one principle of a smart city to be } \\
\text { followed by leaders and practitioners to transform cities into smart ones. In relation to PPP, } \\
\text { few cities informed that they have formalized ICT Partnerships, which reveals a low } \\
\text { perspective related to Public-Private Partnership (PPP) services initiatives. This is due to lack } \\
\text { of law requirements concerning PPP. From the perspective of smart cities, decision-makers } \\
\text { need data, information, and knowledge to be shared among interested parties, in a } \\
\text { transparently and securely, with confidentiality and privacy requirements. }\end{array}$ \\
\hline $\begin{array}{l}\text { People, Skills and } \\
\text { Competencies }\end{array}$ & $\begin{array}{l}\text { This component reflects how cities are involved with knowledge and training concerns. In } \\
\text { this study, a formal ICT training plan (\#14 ICT Training Plan) for employees was the scope } \\
\text { of analysis. Some cities informed about having a formalized training plan and others reported } \\
\text { that the training is under demand. The fact is that a smart city environment is composed of } \\
\text { complexity and cities must keep a continuous ICT professional knowledge as working force. } \\
\text { From a smart cities' perspective, this component leads to the creative and knowledge } \\
\text { requirements for a learning smart city environment. }\end{array}$ \\
\hline $\begin{array}{l}\text { Service, Infrastructure, and } \\
\text { Applications }\end{array}$ & $\begin{array}{l}\text { This component refers to cities' services, infrastructure, and applications implemented } \\
\text { towards a smart city environment. In this study, the scope was related to identifying cities } \\
\text { applications initiatives for maintaining a participative digital environment (\#9 E-participation } \\
\text { channels) and cities performance achievement for ICT services (\#16 ICT Indicators). Most of } \\
\text { the cities use e-channels for community engagement, which represents a good practice to } \\
\text { deliver and improve citizens' participation in the context of smart cities. Thus, it is a positive } \\
\text { response from cities. In relation to indicators, São Paulo and Santos presented a set of } \\
\text { indicators ranging from strategic to operational. In some cities, ICT management is } \\
\text { challenging, thus few cities monitor and control the technological environment. From a smart } \\
\text { city perspective, governments must maintain digital solutions, tools, applications, } \\
\text { infrastructure, and service level agreements to achieve strategic goals and local community }\end{array}$ \\
\hline
\end{tabular}


This analysis revealed that some cities provided evidence that they adopt ICT governance practices. However, most cities did not evidence their application.

\subsection{Discussions of lessons learned from cities ICT governance}

Based on the information retrieved from city's requests, websites, and transparency portals several lessons learned, as described in Table 8, were identified.

Table 8. Lessons learned from cities

\begin{tabular}{|l|}
\hline \multicolumn{1}{|c|}{ Description of lessons learned } \\
\hline A smart city project should be part of cities agenda in a collaborative environment with citizens. \\
\hline A smart city project should be part of a strategic driver for IT initiatives in cities modernization. \\
\hline A smart city project should be based on public policies and state government, not on politics government. \\
\hline A smart city project should be part of city initiatives to construct the city of the future. \\
\hline $\begin{array}{l}\text { ICT Strategic and Director Plans are governance instruments that should be used to align cities initiatives with Government } \\
\text { Plan. }\end{array}$ \\
\hline A structured governance approach should be institutionalized in cities. \\
\hline Municipal ICT Policies should be formally issued in cities to drive governance concerns. \\
\hline Governance instruments should be formally institutionalized in cities as good practices. \\
\hline Active transparency procedures towards ICT governance in cities should be in place. \\
\hline ICT Governance focus areas should be mapped and identified to implement a governance based-approach. \\
\hline Cities should seek to establish an IT investment process as a mechanism for management improvement. \\
\hline ICT services development can be performed by third parties, but governance duties should rely on Municipal \\
Administration. \\
\hline Cities should improve transparency initiatives concerning the Access Information Law. \\
\hline Cities should implement active transparency-based on ICT governance. \\
\hline Cities should search for higher maturity concerning ICT governance issues in smart city context. \\
\hline Cities should improve the information available in websites or transparency portals towards ICT governance. \\
\hline Cities should review ICT governance and management structure concerning the duties assigned to their secretariats. \\
\hline Medium and small cities should search for improved ICT governance practices. \\
\hline
\end{tabular}

Thus, cities can take into consideration this study, understand the importance of an ICT governance approach for smart cities, plan and implement good practices in their context.

\subsection{Prospective ICT Governance Practices in Brazilian Smart Cities}

Smart cities projects in Brazilian cities are decentralized in each city municipal secretariats, thus it makes difficult to manage and monitor these initiatives in Brazilian context. From a governance perspective, cities should plan and implement an integrated and holistic approach to conduct smart cities projects as smart city programs. This could be done by structuring smart city as a city program, implementing a program office, establishing formal procedures, issuing municipal decrees, appropriate governance committees and municipal public councils, publicizing the projects as active transparency, and highlighting the projects benefits for citizens. Considering that these plans are long-term, the establishment of a smart program office can be exercised by cities as a governance practice implementation. The establishment of an Information and Communication Technology Municipal Policy centered on IT Governance should also be considered by cities in their smart programs.

Cities' IT functions vary from city to city, depending on their organizational structure. Nevertheless, based on the premises of ICT decentralization and that IT permeates each city secretariats, IT public corporate governance mechanisms should be in place by cities' leaders. Therefore, cities should plan and implement a governance system structure that reflects those premises based on project prioritization, budgets, decisionmaking, separation of duties, and metrics for ICT evaluation, direction, and monitoring. 
Strategic governance instruments such as the ICT Strategic Plan (PETIC) and the ICT Director Plan (PDTIC), and related artefacts should be conceived as part of cities ICT governance policies and adopted as institutionalized practices to plan and implement ICT smart cities initiatives related to digital services. These governance instruments can be instituted together with a Smart Cities Information Technology Master Plan (PDTCI), based on strategic management units needs and monitored by cities' leaders to achieve a broad approach.

Considering that most smart cities initiatives are derived from digital technologies perspectives, an IT risk approach should be part of cities governance process structure. The ISO 31000, the NIST cybersecurity framework, and the COBIT 2019 are examples of good practices that cities can customize and adopt into their organizational environment.

Cities budget is also an important issue related to smart cities projects implementation. Thus, city leaders should map and consider ICT investments when defining its Annual Budget Law (LOA). The IT investment plan can be elaborated together with cities PETIC to reflect their needs aligned with the strategic plan. A set of five fundamental recommendations as action plan is introduced in Figure 5.

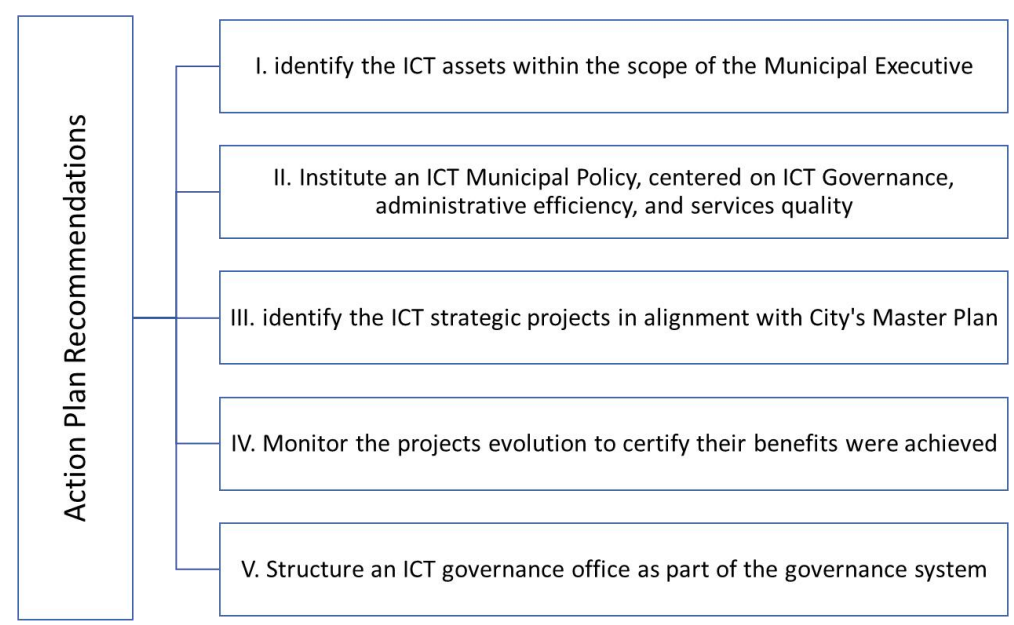

Figure 5. Action plan recommendations

Source: Elaborated by authors

\section{Conclusions and Future Works}

This research investigated the implementation of ICT governance practices based on COBIT 2019 framework for smart city context by analyzing forty-five Brazilian cities based on cities best ranked at the connected smart city index. The analysis encompassed smart cities' governance initiatives by focusing on the seven governance components proposed by the related standard.

A motivation for conducting this research was based on a survey that evidenced a limited number of publications in Information Systems that addressed ICT governance practices using the COBIT framework in the context of smart cities [Reis et al. 2020] and on the studies conducted in Brazilian municipalities [Reis et al. 2020b] [Reis et al. 2021]. 
ICT governance consists of leadership, policies, standards, organizational structure, methods, and processes to ensure that IT supports and enhances cities' objectives and strategies by adding value to public services, leaded by executives and top management. Thus, in smart city governance, strategic initiatives should be guided by cities executive body, in the figure of its mayor, by institutionalizing smart city projects or plans, structured in accordance to cities and citizen's needs.

This research revealed that few municipalities evidenced the implementation of good governance practices based on COBIT 2019 and effective initiatives towards transparency procedures based on the Information Access Law. Thus, this study can work as a diagnostic for cities to introduce good governance practices, learn with cities practices, and establish a set of good governance practices. From a public management perspective towards smart cities environment, cities should seek to institutionalize policies and standards related to ICT governance to set good practices that encompass the management and use of resources, acceptable level of risk, and strategic alignment from an e-government perspective.

Considering the definitions of smart cities and ICT governance and the result of this study, Brazilian cities face a set of challenges to become effectively intelligent. Thus, cities need to make efforts to implement ICT governance practices to improve government management efficiency. This is due to the fact that ICT represents a dimension of the smart city framework [Gil-Gárcia et al. 2015]. Thus, a set of good governance practices is due for cities to improve their internal processes and to deliver value to citizens.

This work contributes to the scientific community, academia experts, and practitioners in the area of governance and smart cities because it covers these topics in the Brazilian cities' context. ICT governance is a limited area of study with gaps to be covered in future researches. Thus, this work can also assist governments in the administration and management of municipalities to apply ICT governance requisites in large, mid-cities, and especially in small ones, which lack governance practices implementation.

A limitation of this work is that the artifacts were analyzed, in the light of their existence, under aspects of compliance about the ICT governance concepts and requirements established in the framework COBIT 2019 and in studies based on governance and management practices in cities context. Thus, future works can evaluate the effectiveness of these ICT governance artifacts in the cities, especially in those that replied positively about adopting a governance practice or requisite. Future studies can prospect an ICT governance structure for cities that indicates low maturity based on this study.

Future works may also investigate the effectiveness of each artifact and the process established by the cities to achieve the prospect outputs, complement this initiative, and develop a good practice catalog to be used as a baseline for ICT governance implementation in Brazilian municipalities. The conception of a methodology for ranking Brazilian smart cities based on ICT governance requisites may also be developed as a reference work product. These approaches can be based on standards and practices and consider strategic planning, project management, risk management, stakeholders and partners relationship, resources management, 
investments approval, contracts acquisition, and other related ICT services as fundamentals governance areas of focus.

Study cases can also be applied in cities, as complementary researches. Thus, further analysis may include surveys with experts and interviews with members of municipal governments to understand the challenges and difficulties of adopting ICT governance practices in the cities. Other governance aspects concerning open data procedures related to ICT governance and emerging technologies may also be investigated.

\section{References}

ACC. Association of Corporate Counsel. (2016). Top Ten Tips for Developing an Effective Code of Conduct.

Ahvenniemi, H., Huovila, A., Pinto-Seppä, I., \& Airaksinen, M. (2017). What are the differences between sustainable and smart cities? Cities, 60, 234-245. https://doi.org/10.1016/j.cities.2016.09.009.

Bianchi, I. S., Sousa, R. D., Pereira, R., Luciano, E. (2017). IT Governance Structures in Brazilian, Dutch and Portuguese Universities. Procedia Computer Science, 121, 927933. https://doi.org/10.1016/j.procs.2017.11.120.

Bolívar, M. P. R. (2016). Characterizing the Role of Governments in Smart Cities: A Literature Review. In: Gil-Garcia J., Pardo T., Nam T. (eds) Smarter as the New Urban Agenda. Public Administration and Information Technology, vol 11. Springer, Cham. https://doi.org/10.1007/978-3-319-17620-8 3.

Boscarioli, C.; Araujo, R. M.; Maciel, R. S. P. (2017). I GranDSI-BR - Grand Research Challenges in Information Systems in Brazil 2016-2026. Special Committee on Information Systems (CE-SI). Brazilian Computer Society (SBC). ISBN: [978-857669-384-0]. 2017. 184p.

Brasil, IBGE (2017). Instituto Brasileiro de Geografia e Estatística, IBGE. Disponível em https://cidades.ibge.gov.br/brasil/panorama.

Brasil, Lei $\mathrm{n}^{\circ} 10.257$ (2001). Estatuto da Cidade. Disponível em http://www.planalto.gov.br/ccivil_03/leis/leis_2001/110257.htm.

Brasil, Lei $\mathrm{n}^{\circ} 12.527$ (2011). Acesso a informações. Disponível em http://www.planalto.gov.br/ccivil_03/ ato2011-2014/2011/lei/112527.htm.

Brasil. Ministério do Planejamento, Desenvolvimento e Gestão. (2018). Estratégia de Governança Digital: Transformação Digital - cidadania e governo/Ministério do Planejamento, Desenvolvimento e Gestão, Secretaria de Tecnologia da Informação e Comunicação. -- Brasília: MP, 2018. 56p.: il.

Brasil, Lei no 13.709, (2018b). Lei Geral de Proteção de Dados. Disponível em www.planalto.gov.br.

CFA, Índice de Governança Municipal. IGM-CFA. (2018). Ranking dos Grupos IGMCFA. Disponível em http://www.igm.cfa.org.br/.

Caragliu, A., Del Bo, C., Nijkamp, P. (2011). Smart cities in Europe. Journal of Urban Technology, 18(2), 65-82. https://doi.org/10.1080/10630732.2011.601117. 
Connected Smart Cities. (2020). Urban Systems. Available at: https://d335luupugsy2.cloudfront.net/cms/files/48668/1600973008Ranking_CSC 20 20.pdf. Access on Sept. 24th, 2020.

Connolly, N., Maccani, G., Donnellan, B. (2017). IT Governance in Smart Cities: A Conceptual Framework. ICIS.

De Haes, S., Van Grembergen, W. (2009). An Exploratory Study into IT Governance Implementations and its Impact on Business/IT Alignment. IS Management. 26. 123137. https://doi.org/10.1080/10580530902794786.

De Haes, S., Van Grembergen, W., Debreceny, R. (2013). COBIT 5 and Enterprise Governance of Information Technology: Building Blocks and Research Opportunities. Journal of Information Systems. https://doi.org/10.2308/isys-50422.

De Haes S., Van Grembergen W., Joshi A., Huygh T. (2019) COBIT as a Framework for Enterprise Governance of IT. In: Enterprise Governance of Information Technology. Management for Professionals. Springer, Cham.

GIL, A. C. (2010). Como elaborar projetos de pesquisa. 5. ed. São Paulo: Atlas.

Gil-Gárcia, J. R.; Pardo, T.; Nam, T. (2015) What makes a city smart? Identifying core components and proposing an integrative and comprehensive conceptualization. Information Polity, vol. 20, no. 1, pp. 61-87.

Héroux, S.; Fortin, A. (2017). Exploring the influence of executive management diversity on IT governance. CHAIRE DínformationFinanciére et Organisationnelle ESQ UQÀM, (514), 1-33. https://doi.org/10.4301/s1807-17752017000300007.

Hollands, R. G. (2008). Will the real smart city please stand up? Intelligent, progressive or entrepreneurial? City, 12(3), 303-320. https://doi.org/10.1080/13604810802479126.

Huang, R., Zmud, R.W., Price, R.L. (2010). Influencing the effectiveness of IT governance practices through steering committees and communication policies, European Journal of Information Systems, 19(3), pp.288-302. https://doi.org/10.1057/ejis.2010.16.

ISACA. (2012). COBIT 5: A Business Framework for the Governance and Management of Enterprise IT. Rolling Meadows, IL: ISACA.

ISACA. (2018). COBIT 2019 Framework: Introduction and Methodology. Rolling Meadows, IL: ISACA.

ISACA. (2018b). COBIT 2019 Framework: Governance and Management Objectives. Rolling Meadows, IL: ISACA.

ISO. International Organization for Standardization (ISO). 2015. International Electrotechnical Commission (IEC). Smart Cities, Preliminary Report 2015, ISO/IEC JTC 1.

ITGI. (2003). Board Briefing on IT Governance, Second Edition. Available at https:/www.oecd.org/site/ictworkshops/year/2006/37599342.pdf.

Joshi, A., Huygh, T., Haes, S., Grembergen, W. (2018). An Empirical Assessment of Shared Understanding in IT Governance Implementation. HICSS, 2018. https://doi.org/10.24251/HICSS.2018.616.

iSys: Revista Brasileira de Sistemas de Informação (isys: Brazilian Journal of Information Systems) 
Jucevicius, R., Patašiene, I., Patašius, M. (2014). Digital Dimension of Smart City: Critical Analysis. Procedia - Social and Behavioral Sciences, 156. https://doi.org/10.1016/j.sbspro.2014.11.137.

Kobayashi, A. R. K., Kniess, C. T., Serra, F. A. R., Ferraz, R. R. N., Ruiz, M. S. (2017). Cidades inteligentes e sustentáveis: estudo bibliométrico e de informações patentárias. International Journal of Innovation, 5(1), 77-96. http://dx.doi.org/10.5585/iji.v5i1.159.

Lakatos, EM; Marconi, MA. (2006). Fundamentos de Metodologia Científica. In: 6 São Paulo: Ed. Atlas.

Nam, T., Pardo, T.A. (2011). Conceptualizing smart city with dimensions of technology, people, and institutions. In: 12th Annual International Digital Government Research Conference. ACM. https://doi.org/10.1145/2037556.2037602.

Pereira, G. V., Parycek, P., Falco, E., Kleinhans, R. (2018). Smart governance in the context of smart cities: A literature review. Information Polity. https://doi.org/10.3233/IP-170067.

Reis, L. Diogo, Ferreira, S. B. L., Bernardini, F. C., Cappelli, C. (2020). Towards a COBIT5 Approach to ICT Governance Requirements in Smart Cities. ICEGOV. $13^{\text {th }}$ International Conference on Electronic Governance. https://doi.org/10.1145/3428502.3428600.

Reis, L. Diogo, Bernardini, F.C., Cappelli, C, Ferreira, S. B. L. (2020b). ICT Governance in the Context of Smart Cities: An Exploratory Study in Municipalities in the state of Rio de Janeiro. In: Workshop on Computing Applied to E-Government (WCGE), 8., 2020, Cuiabá. Anais [...]. Porto Alegre: Sociedade Brasileira de Computação, 2020. p. 24-35. DOI: https://doi.org/10.5753/wcge.2020.11255.

Reis, L. Diogo, Bernardini, F. C., Ferreira, S. B. L., Cappelli, C. (2021). An ICT governance analysis for the digital and smart transformation of Brazilian municipalities. In DG.O2021: The 22nd Annual International Conference on Digital Government Research (DG.O'21). Association for Computing Machinery, New York, NY, USA, 327-338. DOI: https://doi.org/10.1145/3463677.3463729.

Reis, L. Diogo, Bernardini, F., Cappelli, C., Ferreira, S. B. L. (2021b). A transformação inteligente das cidades brasileiras na perspectiva da governança de TIC. In Anais do IX Workshop de Computação Aplicar em Governo Eletrônico, (pp. 227-238). Porto Alegre: SBC. https://doi.org/10.5753/wcge.2021.15991.

SISP, Guia de Governança de TIC. (2017). Ministério do Planejamento, Desenvolvimento e Gestão. Disponível em http://www.sisp.gov.br/.

Weill, P., Broadbent, M. (2000). Managing IT infrastructure: a strategic choice. In: Zmud, R., (Ed.), Framing the Domains of IT Management: Projecting the Future Through the Past, Pinnaflex Educational Resources, Cincinnati, $\mathrm{OH}$.

Weill, P. and Ross, J. W. (2004). IT Governance on One Page. MIT Sloan Working Paper No. 4517-04; CIS Research Working Paper No. 349. Available at SSRN: https://ssrn.com/abstract $=664612$. 